\title{
SISTEM PENDUKUNG KEPUTUSAN DALAM MENENTUKAN BUAH PISANG YANG PALING DIMINATI
}

\author{
Irianto $^{1^{*}}$, Sudarmin $^{1}$ \\ ${ }^{1}$ Sistem Informasi, STMIK Royal Kisaran \\ email : *Irianto2121212@gmail.com
}

\begin{abstract}
Indonesia has a variety of plants that can produce many different kinds of fruit from farmers, especially on average in each region has farmers who have crops that are suitable and in accordance with the conditions of their respective regions. Banana is one of the most consumed fruits by the people. The banana plant farmers basically have a way to determine their own characteristics or character to determine the good or good fruit and suitable for consumption. Many farmers or fruit enthusiasts often find it difficult to determine the best fruit on bananas, with an alternative available decision support system with the FMCDM method to choose the best fruit from bananas. Fuzzy Multi Criteria Decision Making (FMCDM) is a decision making method that aims to determine the best alternative decisions from a number of alternatives based on certain criteria that will be taken into consideration. From the results of calculations using the above software, the results obtained are alternative (A3) obtaining the largest total integral value compared to other alternatives.
\end{abstract}

Keywords: Banana; decision support system; fuzzy multi criteria decision making

\begin{abstract}
Abstrak: sebagai negara agraris Indonesia mempunyai ragam tanaman yang dapat menghasilkan banyak bermacam buah hasil petani, terlebih rata rata di setiap daerah mempunyai petani yang mempunyai tanaman yang cocok dan sesuai dengan kondisi daerah masing masing. Pisang merupakan salah buah yang paling banyak di konsumsi oleh masyarakat. Adapun petani tanaman buah pisang pada dasarnya mempunyai cara untuk menentukan ciri-ciri tersendiri atau karakter untuk menentukan buah bagus atau baik dan layak untuk dikonsumsi. Banyak kadang petani atau peminat buah susah menentukan buah yang terbaik pada buah pisang, dengan adanya alternatif yang ada sistem pendukung keputusan dengan metode FMCDM untuk memilih buah terbaik dari buah pisang. Fuzzy Multi Criteria Decision Making (FMCDM) adalah suatu metode pengambilan keputusan yang bertujuan untuk menetapkan alternatif keputusan terbaik dari sejumlah alternatif berdasarkan beberapa kriteria tertentu yang akan menjadi bahan pertimbangan. Dari hasil perhitungan menggunakan software di atas, diperoleh hasil yaitu alternatif (A3) memperoleh nilai total integral terbesar dibandingkan denganalternatif-alternatif yang lain.
\end{abstract}

Kata Kunci : Buah Pisang; Fuzzy Multi Criteria Decision Making; sistem penunjang keputusan 


\section{PENDAHULUAN}

Pisang merupakan komoditi yang cukup menarik untuk dikembangkan dan ditingkatkan produksinya, jika ditinjau dari aspek perdagangan internasional. Namun, Indonesia yang tercatat sebagai negara produsen ranking keenam dunia, belum tercatat sebagai eksportir buah pisang [1]. Buah pisang adalah produk pertanian yang memiliki nilai ekonomis. Seiring dengan pertumbuhan penduduk yang begitu besar, kebutuhan buah pisang akan semakin meningat. Badan Pusat Statistik dan Direktorat Jenderal Hortikultura pertumbuhan konsumsi pisang di indonesia tumbuh lebih baik sebesar $1.32 \%$ pertahun dibandingkan periode sebelumnya (2002-2010) yang hanya sebesar $0.04 \%$ pertahun[2].

Tingginya konsumsi yang tidak diimbangi perkembangan pertumbuhan akan mengakibatkan kurangnya pasokan buah pisang ke daerah hingga nasional, ini dikarenakan kurangnya minat petani untuk budidaya pisang, selama ini petani lokal hanya membudidayakan pisang yang tahan terhadap penyakit serta bisa beradaptasi dengan alam sekitar bukan buah pisang yang banyak diminati pada masyarakat pada umumnya [3].

Fuzzy Multi Criteria Decision Making sudah banyak digunakan dalam kasus pengambilan keputusan, di antaranya adalah penyuluhan pertanian dan petani dalam keputusan pembuatan penentuan pola tanam yang efektif. menyatakan penentuan lokasi promosi optimal berdasarkan pada beberapa pilihan alternatif dan kriteria pengambilan keputusan yang telah ditentukan oleh pihak produsen. menerapkan Sistem Pendukung Keputusan dengan menggunakan Fuzzy Multi Criteria
Decision Making terbukti mampu untuk menentukan pilihan minat perguruan tinggi.

Pengambil keputusan apapun, keputusan membuat kepastian, di mana semua alternatif yang ada, pengambilan keputusan dalam kondisi ketidakpastian, termasuk alternatif juga beberapa resiko yang dipilih, FMCDM sangat tepat untuk diterapkan di semua alternatif kasus, yang berisi beberapa kriteria yang masing masing memiliki nilai nominal.

Adapun petani tanaman buah pisang pada dasarnya mempunyai cara untuk menentukan ciri-ciri tersendiri atau karakter untuk menentukan buah bagus atau baik dan layak untuk dikonsumsi. Bayak kadang petani atau peminat buah pisang susah menentukan buah yang terbaik pada buah pisang, dengan adanya alternatif yang ada sistem pendukung keputusan dengan metode FMCDM untuk memilih buah terbaik dari buah pisang.

\section{Sistem Pendukung Keputusan}

Terdapat banyak metode yang dapat digunakan oleh pengambil keputusan untuk membantu menemukan solusi atau alternatif yang optimum untuk sebuah masalah. Salah satu metode tersebut adalah Fuzzy MultiCriteria Decision Making [4].

Sistem Pendukung Keputusan (SPK) atau dikenal dengan Decision Support System (DSS), pada tahun 1970an sebagai pengganti istilah System Management Information (MIS) [5].

Fuzzy Multi Criteria Decision Making (FMCDM) adalah suatu Metode pengambilan. Keputusan untuk menetapkan alternatif terbaik dari sejumlah alternatif berdasarkan kriteria tertentu. Kriteria biasanya berupa ukuran-ukuran, aturan-aturan atau standar yang digu- 
nakan dalam pengambilan keputusan [6].

Fuzzy Multi Criteria Decision

Making sudah banyak digunakan dalam kasus pengambilan keputusan, penyuluh pertanian dan petani dalam keputusan pembuatan penentuan pola tanam yang efektif. Penentuan lokasi promosi optimal berdasarkan pada beberapa pilihan alternatif dan kriteria pengambilan keputusan yang telah ditentukan oleh pihak produsen. menerapkan Sistem Pendukung Keputusan dengan menggunakan Fuzzy Multi Criteria Decision Making terbukti mampu untuk menentukan pilihan minat perguruan tinggi [7].

Pengambil keputusan apapun, keputusan membuat kepastian di mana semua alternatif yang ada, pengambilan keputusan dalam kondisi ketidakpastian, termasuk alternatif juga beberapa resiko yang dipilih, FMCDM sangat tepat untuk diterapkan di semua alternatif kasus, yang berisi beberapa kriteria yang masing masing memiliki nilai nominal [8].

Karakteristik Sistem Pendukung Keputusan [9]:

1. Untuk memcahkan masalah yang bersifat semi terstruktur antara pemikiran manusia dan komputer

2. Dengan menggunakan model model analis untuk proses pengolahan data sebagai pemasukan data konvensional

3. Dirancang dengan desain yang sangat mudah untuk diopersikan

4. Mengutamakan aspek fleksibilitas untuk kemampuan adaptasi yang tinggi

Komponen Sistem Pendukung Keputusan digunakan sebagai landasan dalam merancang sistem, adapun gambaran komponen SPK pada gambar $1:[10]$

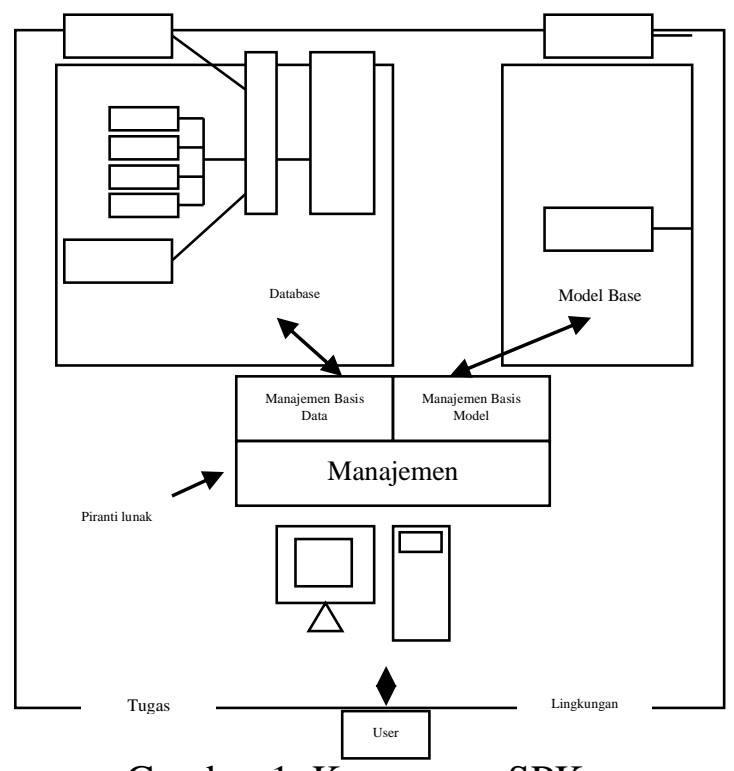

Gambar 1. Komponen SPK

\section{METODE}

Kerangka kerja ini merupakan langkah-langkah yang akan dilakukan dalam rangka penyelesaian masalah yang akan dibahas. Sebagai objek tempat penelitian kami adakan di dua tempat yang berbeda yaitu petani pisang dan pasar tradisional disekitar kota kisaran, dengan mewawancarai lima orang petani serta empat orang pedagang buah khusunya buah pisang. Setelah hasil wawancara observasi dilapangan terkumpul maka data diolah menggunakan metode penalaran Fuzzy Multi Criteria Decision Making untuk melakukan pengolahan data pada proses penentuan buah pisang terbaik pada buah pisang. Yang mana didalamnya terdapat kriteria, Menentukan ranting kecocokan setiap alternatif dengan setiap kreteria, Menghitung indikat Kecocokan Fuzzy, Menghitung drajat keoptimisan. Adapun kerangka kerja dari penelitian ini dapat digambarkan pada gambar 2 berikut: 
DOI: https://doi.org/10.33330/jurteksi.v6i3.636

Available online at http://jurnal.stmikroyal.ac.id/index.php/jurteksi

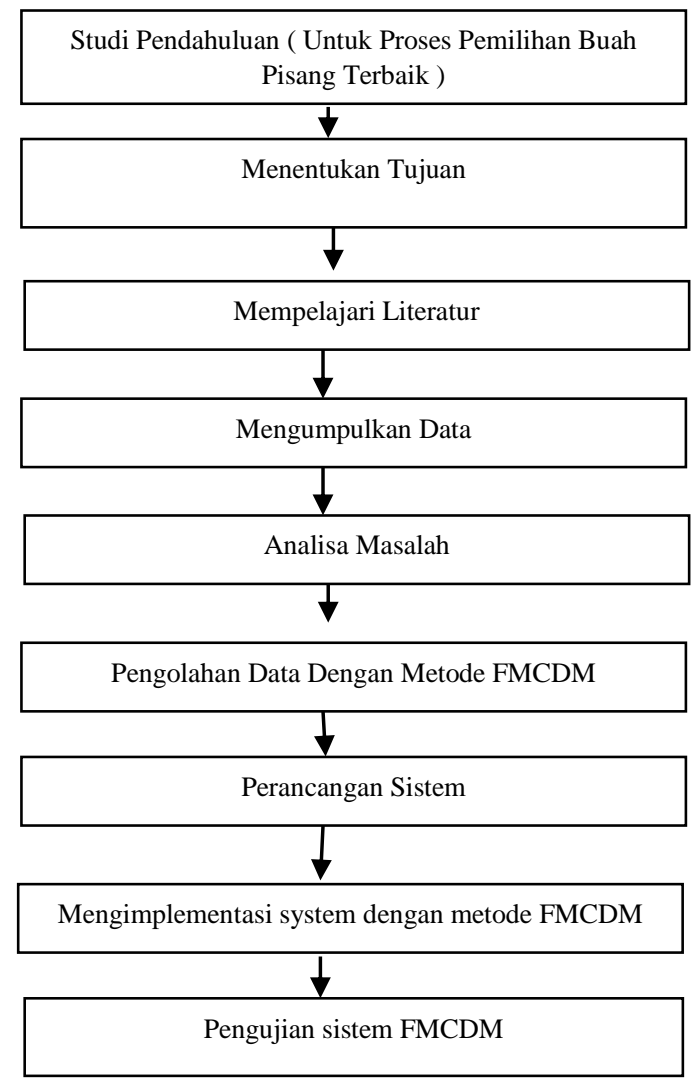

Gambar 2. Kerangka Kerja

\section{Kerangka Kerja}

1. Studi Pendahuluan ( Untuk Proses Pemilihan Buah Pisang Terbaik )

Melakukan penelitian tahap awal untuk mencari informasi-informasi awal mengenai penelitian-penelitian, berhu-bungan dengan penerapan metode Fuzzy Multi Criteria Decision Making untuk menentukan buah pisang terbaik dan faktor-faktor yang mempengaruhi buah pisang pada buah pisang, informasi-informasi ini akan digunakan untuk mengidentifikasi masalah

2. Menentukan Tujuan

Berdasarkan perumusan masalah yang telah dibuat pada tahap sebelumnya, maka tahap penentuan tujuan berguna untuk memperjelas kerangka tentang apa saja yang menjadi sasaran dari penelitian ini. Pada tahap ini ditentukan tujuan dari penelitian ini adalah bagaimana merancang dan mengimplementasikan metode penalaran Fuzzy Multi Criteria Decision Making yang memudahkan dalam proses pengambilan keputusan dalam penentuan pemilihan buah terbaik pada buah pisang.

3. Mempelajari Literatur

Melalui studi literatur, dipelajari teori-teori yang berhubungan dengan dasar matematika, dan khususnya tentang penggunaan metode Fuzzy Multi Criteria Decision Making untuk pengambilan keputusan bertujuan untuk mempermudah dalam proses penentuan pemilihan buah pisang terbaik. Sumbernya berupa jurnal, maupun situs internet yang berhubungan dengan penalaran Fuzzy Multi Criteria Decision Making.

4. Mengumpulkan Data

Data penelitian ini dikumpulkan dari observasi, buku-buku dan situs yang berhubungan dengan penalaran logika Fuzzy Multi Criteria Decision Making serta data dicari dari nara sumber pembudidayaan buah pisang yang berpengalaman pada petani buah pisang.

5. Analisa Masalah

Dari hasil studi literatur yang dilakukan, selanjutnya dilakukan tahap analisis. Pada tahap ini, dianalisa lebih mendalam tentang pengolahan data dari program petani budidaya buah pisang dan akan dirancang dengan meng-gunakan penalaran Fuzzy Multi Criteria Decision Making dan nantinya petani dapat mengambil keputusan, 
sehingga setiap menentukan buah pisang terbaik dengan keahlian dan keterampilan yang mereka miliki. Langkah pertama yang dilakukan adalah identifikasi masalah.

6. Pengolahan Data dengan Metode FMCDM

Dari hasil pengumpulan data selanjutnya dilakukan analisis untuk membuat disain atau rancangan. Setelah itu digunakan metode penalaran Fuzzy Multi Criteria Decision Making untuk melakukan pengolahan data pada proses penentuan buah pisang terbaik pada buah pisang.

7. Perancangan Sistem

Pada tahap ini akan dilakukan perancangan model yang cocok untuk permasalahan ini, perancangan input-input parameter yang digunakan berdasarkan datadata yang telah didapat. Adapun tahapan-tahapan peran-cangan adalah : (a)Perancangan model, Model adalah gambaran dari solusi yang akan dihasilkan, dengan adanya perancangan model ini dapat digambarkan apa yang menjadi tujuan penelitian, sehingga model dapat kita jadikan sebagai pedoman untuk merancang sistem yang telah direncanakan. (b) perancangan input dari data-data yang telah didapatkan dan dianalisa, baik itu dari studi literatur, studi lapangan ataupun wawancara, maka dapat dijadikan referensi untuk merancang input yang akan digunakan di dalam sistem. (c) perancangan parameterparame-ter sistem yang diperlukan. Perancangan parameter dilaku-kan berdasarkan kebutuhan suatu sistem, parameter-parameter ini kemudian akan dijadikan data input awal untuk dilakukan pengolahan dengan menggu-nakan Web Browser

8. Mengimplementasi Sistem dengan metode FMCDM

Berdasarkan pengolahan data yang telah diperoleh maka pada tahap implementasi dilakukan pengujian dari masing-masing kriteria penentuan buah terbaik. Pengolahan data dilakukan dengan menggu-nakan metode Fuzzy Multi Criteria Dicision Making (FMCDM) untuk menghasilkan kesesuaian penentuan buah terbaik pada buah pisang. Implementasi ini menggunakan perangkat lunak Web Browser yang berjalan pada sistem operasi minimal menggunakan windows xp. Perangkat keras yang digunakan minimal setara dengan spesifikasi intel Pentium III.

9. Pengujian Sistem FMCDM

Pengujian dilakukan untuk membandingkan hasil yang didapatkan pada tahap implementasi sistem yang dibuat. Apakah hasil yang didapat sesuai dengan pengujian yang dilakukan, pada tahap ini, dilakukan penilaian apakah perangkat lunak yang dikembangkan telah sesuai dengan tujuan yang diharapkan. Adapun teknik pengujian data ini adalah dengan menguji coba seluruh spesifikasi terstruktur dan sistem secara keseluruhan. Proses pengujian sistem diperlukan bertu-juan untuk memastikan sudah benar dan sesuai dengan karakteristik yang ditetapkan sebelumnya. Berikut ini diuraikan meka-nisme pengujian yang dilakukan, yaitu : (a) Menentukan hasil yang akan diharapkan sebagai faktor prediksi terhadap buah terbaik proses perhitungan manual. (b) Menjalankan 
DOI: https://doi.org/10.33330/jurteksi.v6i3.636

Available online at http://jurnal.stmikroyal.ac.id/index.php/jurteksi

kasus pengujian sistem karakter buah.

Melakukan perbandingan hasil pengujian penilaian buah terbaik dengan hasil prediksi karakter yang diharapkan, jika terdapat perbedaan hasil maka akan dilakukan perbaikan sistem sesuai dengan kesalahan yang ditemukan.

\section{Arsitektur Sistem Pengolahan Data}

Arsitektur proses pengolahan data pemilihan buah terbaik pada buah pisang dapat dilihat pada gambar 3 berikut:

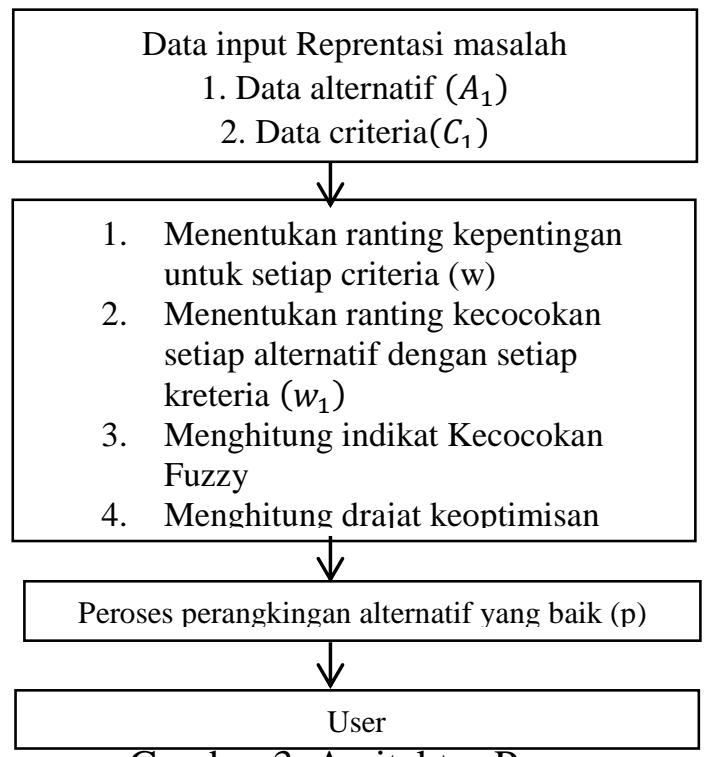

Gambar 3. Arsitektur Proses

Buah pisang terdiri dari berbagai jenis, banyak petani atau peminat yang ingin mengkonsumsi buah pisang dan banyak juga yang membudidayakan buah pisang tersebut. Adapun banyak manfaat dari buah pisang seperti banyak sekali kandungan nutrisi yang bermanfat bagi tubuh yang terdapat pada buah pisang. Dalam proses pemilihan buah terbaik pada buah pisang yang dilakukan dengan menggunakan Fuzzy Multi Criteria Decision Making, diperlukan kriteria-kriteria, bobot kepentingan setiap kriteria dan rating kecocokan alternatif terhadap kriteria untuk melakukan perhitungan sehingga akan didapatkan alternatif terbaik. Dalam hal ini alternatif terbaik dimaksud adalah buah terbaik pada buah pisang.

Pada Alternatif $\mathrm{A}_{1}$

$$
\begin{aligned}
& \mathrm{Y}_{1}=1 / 9((\mathrm{~T} * \mathrm{C})+(\mathrm{C} * \mathrm{~B})+(\mathrm{C} * \\
& \mathrm{C})+(\mathrm{C} * \mathrm{C})+(\mathrm{C} * \mathrm{~B})+(\mathrm{ST} * \\
& \mathrm{C})+(\mathrm{C} * \mathrm{C})+(\mathrm{T} * \mathrm{C})+(\mathrm{ST} * \\
& \text { SB)) } \\
& =1 / 9((1 * 0.75)+(0.75 * 1)+ \\
& \left(0.75^{*} 0.75\right)+\left(0.75^{*} 0.75\right)+(0.75 \\
& * 1)+(1.5 * 0.75)+(0.75 * 0.75) \\
& +(1 * 0.75)+(1.5 * 1.5))= \\
& 0.895833
\end{aligned}
$$
kepentigan masing-masing alternatif terhadap kriteria, fungsi keanggotaan bilangan fuzzy yang digunakan adalah fungsi bilangan fuzzy segitiga, yang fungsi keanggotaannya telah dikemukakan pada persamaan (3) yaitu:

$$
\begin{gathered}
\mu A[x]= \\
0 ; x<\text { a atau } x>c \\
\left\{\begin{array}{cl}
(x-a) /(b-a) ; & a \leq x \leq b \\
(c-x) /(c-b) ; & b \leq x \leq c
\end{array}\right.
\end{gathered}
$$

memperlihatkan grafik fungsi keanggotaan bobot kepentingan kriteria (W) dengan menggunakan himpunan fuzzy segitiga, 


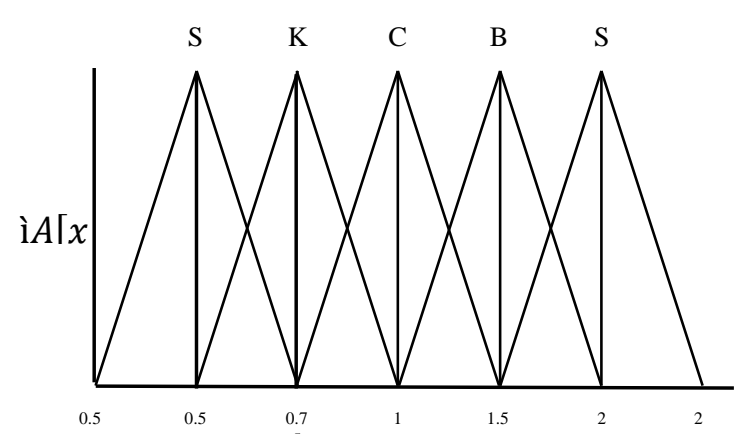

Gambar 4. Fungsi Keanggotaan Untuk Bobot Setiap Kriteria Dengan Himpunan Bilangan Fuzzy Segitiga

Di mana pada alternatif $A_{1}$ untuk mencari index kecocokan untuk setiap alternatif $\mathrm{Y}_{1}, \mathrm{Q}_{1}$, dan $\mathrm{Z}_{1}$ diambil dari Tabel 1 Ranting Kecocokan Setiap Alternatif Terhadap Setiap Kriteria, dan diambil setiap alternatif pada tabel Tabel 4.5 Ranting Kepentingan dan Ranting Kecocokan Setiap Kriteria Untuk Alternatif $A_{1}$. Dari hasil perhitungan di atas, terlihat bahwa pada alternatif $\mathrm{A}_{1}$ Buah pisang Raja memiliki indeks kecocokan fuzzy: 0.895833; 1.666667; 2.86111 .

Tabel 1. Nilai Total Integral Setiap Alternatif

\begin{tabular}{cccc}
\hline \multicolumn{4}{c}{ Alternatif } \\
\hline \multirow{2}{*}{$\begin{array}{c}\text { Alterna } \\
\text { tif }\end{array}$} & $\propto=0$ & $\propto=0.5$ & $\propto=1$ \\
\cline { 2 - 4 } & \multicolumn{3}{c}{ Nilai Total Integral } \\
\hline $\mathrm{A}_{1}$ & 1.28125 & 1.772569444 & 2.263888889 \\
\hline $\mathrm{A}_{2}$ & 1.298611111 & 1.795138889 & 2.291666667 \\
\hline $\mathrm{A}_{3}$ & 1.652777778 & 2.1875 & 2.722222222 \\
\hline $\mathrm{A}_{4}$ & 1.472222222 & 1.965277778 & 2.458333333 \\
\hline $\mathrm{A}_{5}$ & 1.434027778 & 1.973958333 & 2.513888889 \\
\hline $\mathrm{A}_{6}$ & 1.270833333 & 1.788194444 & 2.305555556 \\
\hline
\end{tabular}

Terlihat bahwa $\mathrm{A}_{3}$ memiliki total integral terbesar berapapun derajat keoptimisannya, sehinga petani atau peminat yang ingin mengkonsumsi buah terbaik pada buah pisang terpilih dengan terbaik.

Setelah dilakukan analisis ulang dan pengujian terhadap hasil perhitungan manual dengan mengunakan fuzzy nilai total integral, ternyata hasil perhitungan manual yang diperdapat dipertegas kembali kebenarannya oleh peneliti.

Di mana hasil perhitungan yang dilakukan, maka alternatif memilih buah terbaik pada buah pisang, yaitu Buah Pisang Barangan merupakan alternatif baik dari buah pisang yang ada.

Dari perhitungan perangkingan nilai total integral dari semua alternatif yang ada, terlihat bahwa Alternatif $\mathrm{A}_{3}$ kolom integral satu memiliki nilai yang tertinggi, sehingga dapat disimpulkan bahwa alternatif tersebuat adalah alternatif yang terbaik dengan nilai 2.722222222 .

Untuk menghasilkan hasil akhir di perlukan mendistribusikan indeks kecocokan fuzzy, dan dengan mengambil derajat keoptimisan $(\alpha)=0$ (tidak optimis), $\alpha=0.5$ dan $\alpha=1$ (sangat optimis), maka akan diperoleh nilai integral untuk setiap alternatif. Pada kolom $\alpha=0$ di gunakan seluruh hasil kecocokan ditambahkan dan di bagi $1 / 2$ dan untuk menemukan hasil pada kolom 0.5 dan 1 menggunakan cara yang sama.

\section{SIMPULAN}

Dengan melihat berbagai pembahasan diatas maka didapat simpulan dalam penggunaan FMCDM dalam menentukan buah pisang terbaik. Metode Fuzzy Multi Kriteria decision Making (FMCDM) dapat digunakan untuk menyelesaikan permasalahan yang bersifat multi kriteria dan data ketidakpastian pada penelitian ini yakni Sistem Pendukung Keputusan Penentuan buah terbaik pada buah pisang. Penerapan sistem pendukung keputusan dengan metode Fuzzy Multi Kriteria Decision Making dapat membantu mempermudah 
untuk menentukan sebuah pilihan atau keputusan dalam pemilihan buah yang baik pada buah pisang. sistem ini bisa kita terapkan dengan menggunakan tools yang sudah ada, dan Sistem ini hanya sebagai alat bantu bagi pengambil keputusan dalam menentukan buah terbaik, namun keputusan akhir tetap berada di tangan pengambil keputusan.

\section{UCAPAN TERIMA KASIH}

Ucapan terima kasih kepada Direktorat Riset dan Pengabdian Masyarakat Direktorat Jenderal Penguatan Riset dan Pengembangan Kemenristek DIKTI, atas pendanaan penelitian dan pubilkasi Sesuai dengan Kontrak Penelitian Tahun Anggaran 2020.

\section{DAFTAR PUSTAKA}

[1] T. K. Putri et al., "Pemanfaatan jenis-jenis pisang (banana dan plantain) lokal Jawa Barat berbasis produk sale dan tepung," Kultivasi, vol. 14, no. 2, 2015 ,

[2] S. Kusumadewi, I. Guswaludin, K. Sistem, P. Keputusan, and D. Support, "Fuzzy Multi-Criteria Decision Making," vol. 3, no. 1, pp. 25-38, 2005.

[3] Bappenas, "Outlook Komoditas Pisang," Komod. Pertan. Sub Sekt. Hortik., vol. 19, no. 7, p. 28, 2016.

[4] D. Puspitorini, "Sistem Pendukung Keputusan Untuk Menentukan Pilihan Minat Perguruan Tinggi Di Kota Jambi Dengan Menggunakan Fuzzy
Multi Criteria Decision Making," vol. 2011, no. Snati, pp. 17-18, 2011.

[5] T. Kristina, "Sistem Pendukung Keputusan Dengan Menggunakan Metode TOPSIS Untuk Pemilihan Lokasi Pendirian Grosir Pulsa," Paradigma, vol. 20, no. 1, pp. 812, 2018,

[6] N. Kahar and N. Fitri, "Aplikasi Metode Fuzzy Multi Criteria Decision Making (Fmcdm) Untuk Optimalisasi Penentuan Lokasi Promosi Produk," Semin. Nas. Apl. Teknol. Inf. SNATI, vol. 2011, no. Snati, p. A-58-A-63, 2011.

[7] Y. Salim, "Penerapan Fuzzy Multi Criteria Decision Making untuk Menentukan Pemberian Beasiswa," Semin. Nas. Teknol. Inf. dan Multimed., pp. 6-8, 2015.

[8] A. Afrisawati, "Sistem Pendukung Keputusan Penerimaan Pegawai di STMIK Royal Menggunakan Metode Simple Additive Weighting," Jurteksi, vol. 4, no. 1, pp. 43-50, 2017,

[9] S. Motor, S. Pendukung, F. Multi, C. Decision, K. Pemilihan, and S. Motor, "Penerapan Metode FMCDM untuk Pemilihan Sepeda Motor Berbasis Android," vol. 2, no. 1, pp. 28-32, 2020.

[10] A. K. Hidayah, "Sistem Pendukung Keputusan Pemilihan Ketua Badan Eksekutif Mahasiswa Dengan Metode Simple Additive Weighting," JSAI (Journal Sci. Appl. Informatics), vol. 2, no. 1, pp. $92-$ 96, 2019, 